\title{
The Use of Yam Peel Ash as Partial Replacement of Cement Towards Achieving Low Cost Housing
}

\author{
Waheed Oyelola Balogun*, Oluwaseun Olatunji Otunola \\ Civil Engineering Department, Federal Polytechnic, Offa, Nigeria \\ Email address: \\ waheedabefe@yahoo.com (W. O. Balogun),ogamaths@gmail.com (O. O. Otunola) \\ ${ }^{*}$ Corresponding author
}

\section{To cite this article:}

Waheed Oyelola Balogun, Oluwaseun Olatunji Otunola. The Use of Yam Peel Ash as Partial Replacement of Cement Towards Achieving Low Cost Housing. American Journal of Construction and Building Materials. Vol. 5, No. 1, 2021, pp. 15-21.

doi: 10.11648/j.ajcbm.20210501.13

Received: April 8, 2021; Accepted: April 21, 2021; Published: April 30, 2021

\begin{abstract}
Yam Peels are the wastes produced when yam are processed for human consumption. This research investigated the structural strength characteristics of concrete with Yam peel ash (YPA) used as partial substitute for cement. The YPA was subjected to pozzolanicity and setting time tests to ascertain it potential as a pozzolan. Water/cement ratio of 0.6 was used to produce the blended concrete of mix 1:2:4, 1:3:6, 1:4:8 by which cement was replaced partially by YPA at $5 \%, 10 \%, 15 \%$ and $20 \%$ replacement by weight of cement. A total of 64 concrete cubes of size $50 \times 50 \times 50 \mathrm{~mm}$ were molded and cured for 7, 14, 21 and 28 days. While 36 concrete beams of size $50 \times 50 \times 150 \mathrm{~mm}$ were molded and cured for 7 and 28 days. The workability, compressive strength and flexural test were conducted. The result revealed that the water/cement ratio is adequate to make the blended concrete workable. The best $28^{\text {th }}$ day compressive strength of the blended concrete was observed for mix ratio of 1:3:6 at $5 \%$ YPA replacement of cement with a value of $9.857 \mathrm{~N} / \mathrm{mm}^{2}$, an approximate $64 \%$ of the strength of the concrete without replacement of cement. The best flexural strength of the concrete was observed at mix ratio of 1:2:4 at 5\% YPA replacement with a value of $5.112 \mathrm{~N} / \mathrm{mm}^{2}$, an approximate $97 \%$ of the strength of the concrete without replacement of cement. The result further revealed that the increase in \%YPA replacement of cement does not have any significant effect on the density of the test specimens of the blended concrete.
\end{abstract}

Keywords: Yam Peels Ash, Cement, Compressive Strength, Flexural Strength, Concrete

\section{Introduction}

Availability of affordable housing is very essential to the human race because it helps to fulfill human basic need for shelter and improve the vitality of the economics of communities and/or world as a whole [1]. Due to the tremendous increase in the world population, there is high demand for affordable housing, but there is limited supply due to high cost of building/construction materials, high cost of laborand land, government regulations, slow pace of construction due to use of old conventional construction methods etc. $[1,2]$.

According to Ofuyatan, et al. [3], almost $60 \%$ of total cost of constructing an affordable house is ascribed tobuilding/construction materials such as concrete, sandcrete blocks and steel. During this Covid-19 era, there has been remarkable increase in the price of these building materials due to drastic reduction in their production which arise as a result of depletion in resources used and labor required.

Sandcrete blocks and concrete are the most commonly used construction material because of its economical values, resilience, and flexibility [4, 5]. Reference [6] indicated that sandcrete blocks and concrete are important construction because more than $90 \%$ of physical infrastructures in Nigeria are being constructed using them.

Cement is a key ingredient in concrete and sandcrete production. Despite its advantageous use, the production process of cement generates a lot of $\mathrm{CO}_{2}$, reduction of lime stones reserves and high energy demand [7, 8]. These disadvantages have led several researchers to seek out other alternatives to replace cement. Through research, some agricultural byproducts such as rice husk ash [9, 10], banana peel ash [11], cassava peel ash [12-14], corn cob ash [15], sugar cane bagasse ash etc. Have been observed to 
have good cementitious properties and have been effectively used in partial replacement of cement. This has help in drastic reductionof construction cost of houses and effective in reduction disposal of agricultural wastes to the environment at very low cost. Despite these advantages, the availability of some of these agro wastes in large quantity is still a challenge.

Yams (Dioscorea spp.) are staple foods in humid and subhumid tropical countries of the world such as Nigeria. Food and Agriculture Organization (FAO) statistics indicates that Nigeria produced 31 million metric tons of yam tubers in 2007. It is also reported that Nigeria is the single largest producer of yam accounting for about $71 \%$ of total world production [16].

Yam is among the oldest recorded food crop and ranks second after cassava in supply of starch in West Africa [17]. Naturally, yam is rich in starch and produces energy. Yam tubers are peeled and prepared for consumption by boiling, roasting, grilling, frying or pounding boiled tubers. Although several studies show that the waste peels from yam can be used as ingredient for animal feeding, the peels are still largely discarded [18].

Thus, a good way of utilizing Yam Peels is to burn it into ashes and use it for making "high performance concrete" which means high workability and very high early strengths, and long term durable concrete and sandcrete [19].

Thus, this research work shall be focused on the structural behavior of blended cement-yam peel ash concrete.

\section{Materials}

\subsection{Yam Peel Ash (YPA)}

Yam peels were collected from different cafeteria within Offa metropolis, sun dried and was later burnt in an electric furnace (Thermo cline Brand) at $950^{\circ} \mathrm{C}$ for $2 \frac{1}{2}$ hours at the Forgery and Moulding Workshop, Mechanical Engineering Department of the Federal Polytechnic Offa, Kwara State.

\subsection{Aggregates}

Clean river sand, free from waste stone and impurities were used in the production of the blended cement- yam peel ash concrete, while crushed granite of maximum nominal particle size of $19 \mathrm{~mm}$ was used as coarse aggregate.

\subsection{Cement}

The cement used was Dangote Ordinary Portland Cement which conforms to NIS $444-1: 2003$ as evidenced by the certification mark NIS $444-1: 2003$ on the product bags.

\subsection{Water}

Water collected from a borehole within the Federal Polytechnic Offa was used in the mixing of concrete for effective workability. The water was ensured to be free from suspended particles, salts and oil contamination.

\section{Methodology}

\subsection{Chemical Composition Test on YPA}

The chemical composition of YPA was determined by subjecting the sample to analysis using the combination of Atomic Absorption Spectrophotometer and Gravimetric methods at the SMO Laboratory Services, Ibadan, Nigeria.

\subsection{Setting Time Test}

The effect of Yam Peel Ash (YPA) on the setting times (Initial and Final) of cement paste was determined at water content of $21 \%$ using a Vicat plunger.

\subsection{Sample Preparation}

The concrete investigated was of mix ratio of $1: 2: 4,1: 3: 6$ and 1:4:8 (cement and yam peel ash: sand: granite) with a constant water/cement ratio of 0.60 . The cement was replaced with yam peel ash at $0 \%, 5 \%, 10 \%, 15 \%$ and $20 \%$ by weight of cement and mixed with sand and granite as fine and coarse aggregates respectively. Batching of the concrete mix was by weight. The concrete cube moulds of $50 \mathrm{~mm} \mathrm{x}$ $50 \mathrm{~mm} \times 50 \mathrm{~mm}$ and concrete moulds of $150 \mathrm{~mm} \times 150 \mathrm{~mm} \times$ $150 \mathrm{~mm}$ were used. They were first polished with black oil to reduce friction and aid the removal of the concrete cubes before pouring concrete mix. After mixing, each of the moulds was filled with concrete in three layers, and each of these layers was tempered with tamping rod for 25 times. The hand trowel was used to smooth the top of concrete in the moulds after which they were marked for identification. The concrete cubes were allowed to set for 24 hours before removing the mould and then the cubes were taken to curing tanks for curing, and they were carefully placed in the curing tank filled with water. Three (3) set of cubes for each concrete mix were cast and cured for 7, 14, 21 and 28 days. Concrete beams of sizes $150 \times 150 \times 150 \mathrm{~mm}$ were cast and cured for 7 and 28 days.

\subsection{Slump and Density Test}

Slump test was done in accordance with BS 1881 (102) [20] to ensure the workability of the blended concrete, while the density was determined by following the procedures specified in BS1881 (107) [21].

\subsection{Compressive Strength}

After the required age of curing, the concrete cubes were removed from the curing tank and allowed to surface dry after which they were weighed on a balance to obtain the weight of each cube. The weighed cubes were carefully placed in a Universal Testing Machine (UTM) with a capacity of $100 \mathrm{kN}$ at the National Centre for Agricultural Mechanization (NCAM), Idofian, Kwara State. The concrete cubes were crushed at age, 7 days, 14 days, 21 days and 28 days. The compressive test results were downloaded from the UTM. 


\subsection{Flexural Test}

The weighed beams were carefully placed in the Universal Testing Machine (UTM) for maximum, 36 cubes were crushed at age 7 days, and 28 days. The result of the Bending Strength was obtained from Universal Testing Machine (UTM).

\section{Results and Discussions}

\subsection{Chemical Properties of YPA}

The result of the chemical analysis conducted on the Yam Peel Ash (YPA) compared with Ordinary Portland Cement $(\mathrm{OPC})$ chemical properties are presented in Table 1.

Table 1. Chemical composition (\%) of ordinary portland cement (OPC) and yam peel ash (YPA).

\begin{tabular}{|c|c|c|c|c|c|}
\hline \multirow{2}{*}{ S/No } & \multirow{2}{*}{ Parameters } & \multirow{2}{*}{ OPC } & \multicolumn{3}{|l|}{ YPA } \\
\hline & & & 1 & 2 & Average \\
\hline 1 & $\mathrm{SiO}_{2}$ & 6.39 & 35.74 & 35.89 & 35.82 \\
\hline 2 & $\mathrm{Al}_{2} \mathrm{O}_{3}$ & 0.88 & 3.27 & 3.34 & 3.31 \\
\hline 3 & $\mathrm{Fe}_{2} \mathrm{O}_{3}$ & 0.05 & 0.74 & 0.78 & 0.76 \\
\hline 4 & $\mathrm{CaO}$ & 72.26 & 2.04 & 2.11 & 2.08 \\
\hline 5 & $\mathrm{MgO}$ & 2.60 & 1.76 & 1.74 & 1.75 \\
\hline 6 & $\mathrm{~K}_{2} \mathrm{O}$ & 0.39 & 22.51 & 22.46 & 22.5 \\
\hline 8 & $\mathrm{SO}_{2}$ & 0.73 & 0.48 & 0.51 & 0.49 \\
\hline 9 & $\mathrm{CO}_{2}$ & 0.00 & - & - & - \\
\hline 10 & $\mathrm{H} 20$ & 0.62 & - & - & - \\
\hline 11 & Loss of Ignition & 0.98 & 1.72 & 1.74 & 1.73 \\
\hline
\end{tabular}

From Table 1, the chemical composition of the YPAwas observed to different from that of the ordinary Portland cement. The $\mathrm{SiO}_{2}+\mathrm{Al}_{2} \mathrm{O}_{3}+\mathrm{Fe}_{2} \mathrm{O}_{3}$ was less than $50 \%$ or $70 \%$, thus the YPA cannot be classified as Class $\mathrm{C}$ or Class $\mathrm{F}$ pozzolan. The YPA was observed to have high $\mathrm{K}_{2} \mathrm{O}$ and $\mathrm{Na}_{2} \mathrm{O}$ content which could likely lead to alkali-silica reaction.

\subsection{Physical Properties of Blended Cement-YPA Paste}

The results of physical properties of the blended cementYam Peel Ash such as specific gravity, initial and final setting time are presented in Table 2.

Table 2. Physical properties of blended cement-yam peel ash.

\begin{tabular}{llll}
\hline \% of YPA & Specific Gravity & Initial setting time (min) & Final setting time (min) \\
\hline 0 & 2.92 & 120 & 165 \\
10 & 2.89 & 125 & 360 \\
20 & 2.85 & 185 & 375 \\
\hline
\end{tabular}

From Table 2, it was observed that the specific gravity of the paste decrease from 2.92 of the control sample $(0 \%$ yam peel ash content) to 2.85 at 20\% Yam Peel Ash (YPA) replacement of cement. The specific gravity of the Yam Peel Ash paste only (i.e. 100\% YPA) is 2.60 . It is thus concluded that the specific gravity of the paste reduces with increase in the YPA content.

\subsection{Slump Test}

The results of slump test for different mix ratios and different percentage of (yam peels ash) in concrete are as shown in Table 3.

Table 3. Table showing the results of slump test of different mix ratios and different percentage of YPA in concrete cubes.

\begin{tabular}{llllllll}
\hline \multirow{2}{*}{ S/N } & \multirow{2}{*}{ MIX RATIO } & \multicolumn{9}{l}{ SLUMP HEIGHT $(\mathbf{m m})$ WITH PERCENTAGE OF YPA } & \multirow{2}{*}{ REMARK } \\
\cline { 3 - 7 } & & $\mathbf{0 \%}$ & $\mathbf{5 \%}$ & $\mathbf{1 0 \%}$ & $\mathbf{1 5 \%}$ & $\mathbf{2 0 \%}$ & \\
\hline 1. & $1: 2: 4$ & 70 & 55 & 45 & 37 & 15 & True \\
2. & $1: 3: 6$ & 27 & 25 & 35 & 37 & 38 & True \\
4. & $1: 4: 8$ & 35 & 36 & 37 & 38 & 39 & True \\
\hline
\end{tabular}

True slump was exhibited for all the mix ratios and for each increment in the partial replacement of cement. It was observed from Table 3, that the slump value increases with increase in YPA for all mix ratios except for mix ratio of $1: 2: 4$. Thus it can be concluded that workability of the concrete improves with increase in the YPA content.

\subsection{Density Test}

The mean densities of concrete cubes and flexural beams of different mix ratios; 1:2:4, 1:3:6, and 1:4:8 of different percent of pozzolanic (YPA); $0 \%, 5 \%, 10 \%, 15 \%, 20 \%$ for curing age between 7- 28 days were given in tables 4 to 9 . The result reveal that density of all concrete cubes produced fall within the range of $2000 \mathrm{Kg} / \mathrm{m}^{3}-2240 \mathrm{Kg} / \mathrm{m}^{3}$, while density of flexural beams produced fall within the range of $2466 \mathrm{Kg} / \mathrm{m}^{3}-2644 \mathrm{Kg} / \mathrm{m}^{3}$. The result revealed that the increase in \%YPA replacement of cement does not have any significant effect on the density of the test specimens of the blended concrete. 
Table 4. Table showing density of concrete cubes of mix ratio $1: 2: 4\left(\mathrm{~kg} / \mathrm{m}^{3}\right)$.

\begin{tabular}{|c|c|c|c|c|}
\hline \multirow{2}{*}{ \%YPAREPLACEMENT } & \multicolumn{4}{|c|}{ DENSITY VALUES $\left(\mathrm{kg} / \mathrm{m}^{3}\right)$ AT DIFFERENT CURING DAYS } \\
\hline & 7DAYS & 14 DAYS & 21DAYS & 28DAYS \\
\hline 0 & 2000 & 2080 & 2160 & 2240 \\
\hline 5 & 2000 & 2080 & 2160 & 2240 \\
\hline 10 & 2000 & 2080 & 2160 & 2240 \\
\hline 15 & 2000 & 2080 & 2160 & 2240 \\
\hline 20 & 2000 & 2080 & 2160 & 2240 \\
\hline
\end{tabular}

Table 5. Table showing density of concrete cubes of mix ratio 1:3:6 $\left(\mathrm{kg} / \mathrm{m}^{3}\right)$.

\begin{tabular}{|c|c|c|c|c|}
\hline \multirow{2}{*}{ \%YPAREPLACEMENT } & \multicolumn{4}{|c|}{ DENSITY VALUES $\left(\mathrm{kg} / \mathrm{m}^{3}\right)$ AT DIFFERENT CURING DAYS } \\
\hline & 7DAYS & 14 DAYS & 21DAYS & 28DAYS \\
\hline 0 & 2000 & 2080 & 2160 & 2240 \\
\hline 5 & 2000 & 2080 & 2160 & 2240 \\
\hline 10 & 2000 & 2080 & 2160 & 2240 \\
\hline 15 & 2000 & 2080 & 2160 & 2240 \\
\hline 20 & 2000 & 2080 & 2160 & 2240 \\
\hline
\end{tabular}

Table 6. Table showing density of concrete cubes of mix ratio 1:4:8 $\left(\mathrm{kg} / \mathrm{m}^{3}\right)$.

\begin{tabular}{|c|c|c|c|c|}
\hline \multirow{2}{*}{ \%YPAREPLACEMENT } & \multicolumn{4}{|c|}{ DENSITY VALUES $\left(\mathrm{kg} / \mathrm{m}^{3}\right)$ AT DIFFERENT CURING DAYS } \\
\hline & 7DAYS & 14 DAYS & 21DAYS & 28DAYS \\
\hline 0 & 2000 & 2080 & 2160 & 2240 \\
\hline 5 & 2000 & 2080 & 2160 & 2240 \\
\hline 10 & 2000 & 2080 & 2160 & 2240 \\
\hline 15 & 2000 & 2080 & 2160 & 2240 \\
\hline 20 & 2000 & 2080 & 2160 & 2240 \\
\hline
\end{tabular}

Table 7. Table showing density of flexural beams of mix ratio $1: 2: 4\left(\mathrm{~kg} / \mathrm{m}^{3}\right)$.

\begin{tabular}{lll}
\hline \multirow{2}{*}{$\%$ YPAREPLACEMENT } & \multicolumn{2}{l}{ DENSITYTOF CONCRETE BEAM (kg/m $\left.{ }^{\mathbf{3}}\right)$} \\
\cline { 2 - 3 } & 7DAYS & 28DAYS \\
\hline 0 & 2000 & 2240 \\
5 & 2000 & 2240 \\
10 & 2000 & 2240 \\
15 & 2000 & 2240 \\
20 & 2000 & 2240 \\
\hline
\end{tabular}

Table 8. Table showing density of flexural beams of mix ratio 1:3:6 $\left(\mathrm{kg} / \mathrm{m}^{3}\right)$.

\begin{tabular}{lll}
\hline \multirow{2}{*}{$\%$ YPAREPLACEMENT } & \multicolumn{2}{l}{ DENSITYTOF CONCRETE BEAM $\left(\mathrm{kg} / \mathbf{m}^{\mathbf{3}}\right)$} \\
\cline { 2 - 3 } & 7DAYS & 28DAYS \\
\hline 0 & 2000 & 2240 \\
5 & 2000 & 2240 \\
10 & 2000 & 2240 \\
15 & 2000 & 2240 \\
20 & 2000 & 2240 \\
\hline
\end{tabular}

Table 9. Table showing density of flexural beams of mix ratio 1:4:8 $\left(\mathrm{kg} / \mathrm{m}^{3}\right)$.

\begin{tabular}{|c|c|c|}
\hline \multirow{2}{*}{ \%YPAREPLACEMENT } & \multicolumn{2}{|c|}{ DENSITYTOF CONCRETE BEAM $\left(\mathrm{kg} / \mathrm{m}^{3}\right)$} \\
\hline & 7DAYS & 28DAYS \\
\hline 0 & 2000 & 2240 \\
\hline 5 & 2000 & 2240 \\
\hline 10 & 2000 & 2240 \\
\hline 15 & 2000 & 2240 \\
\hline 20 & 2000 & 2240 \\
\hline
\end{tabular}

\subsection{Compressive and Flexural Strength}

Figures 1 to 6 shows the average compressive strength of concrete cubes after being cured 7, 14, 21 and 28days and flexural strength of concrete beams after being cured for 7 and 28days of different mix ratio and varying replacement of cement by YPA. The compressive strength of Cement-YPA blended concrete decreases as the YPA content increases. The best $28^{\text {th }}$ day average compressive strength of the blended concrete was observed for mix ratio of 1:3:6 at 5\% YPA replacement of cement with a value of $9.857 \mathrm{~N} / \mathrm{mm} 2$, an approximate $64 \%$ of the strength of the concrete without YPA replacement. Similar trend was observed for flexural strength as for the compressive strength. The flexural strength of 
Cement-YPA blended concrete decreases as the YPA content increases for all mix ratios. The best flexural strength of the concrete was observed at mix ratio of 1:2:4 at 5\% YPA replacement with a value of $5.112 \mathrm{~N} / \mathrm{mm} 2$, an approximate $97 \%$ of the strength of the concrete without YPA replacement.

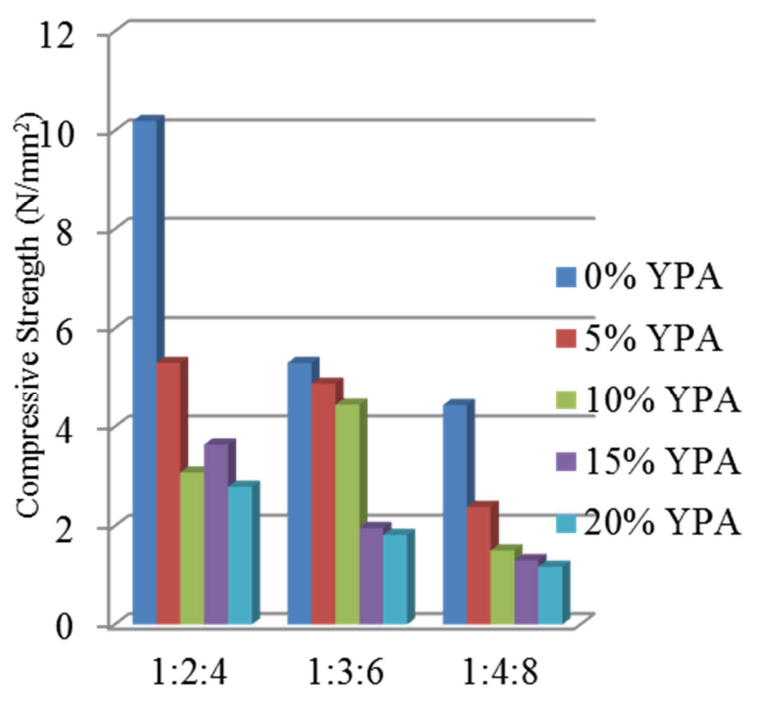

Mix Ratios

Figure 1. Compressive strength of concrete cubes for 7 days.

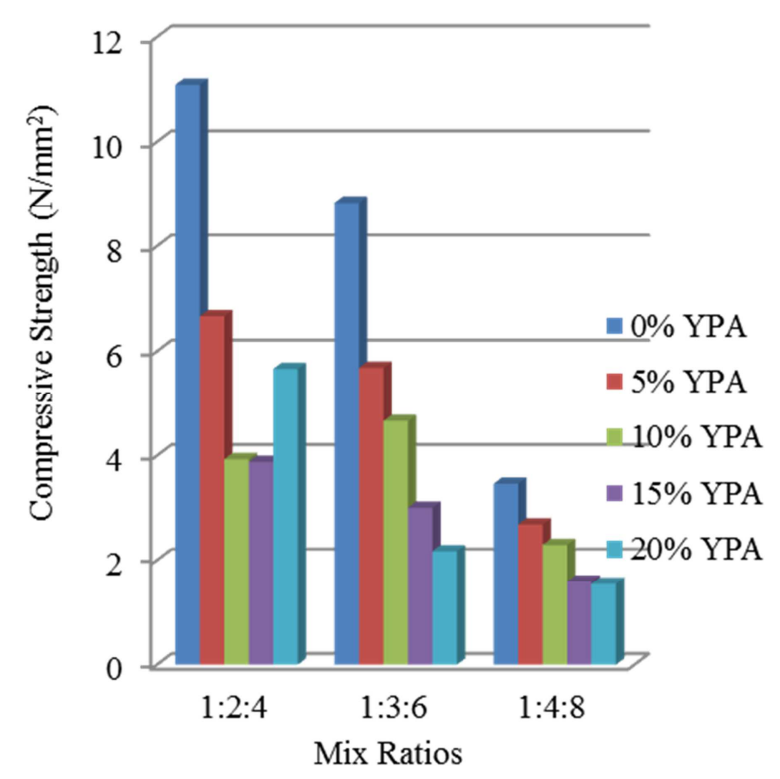

Figure 2. Compressive strength of concrete cubes for 14days.

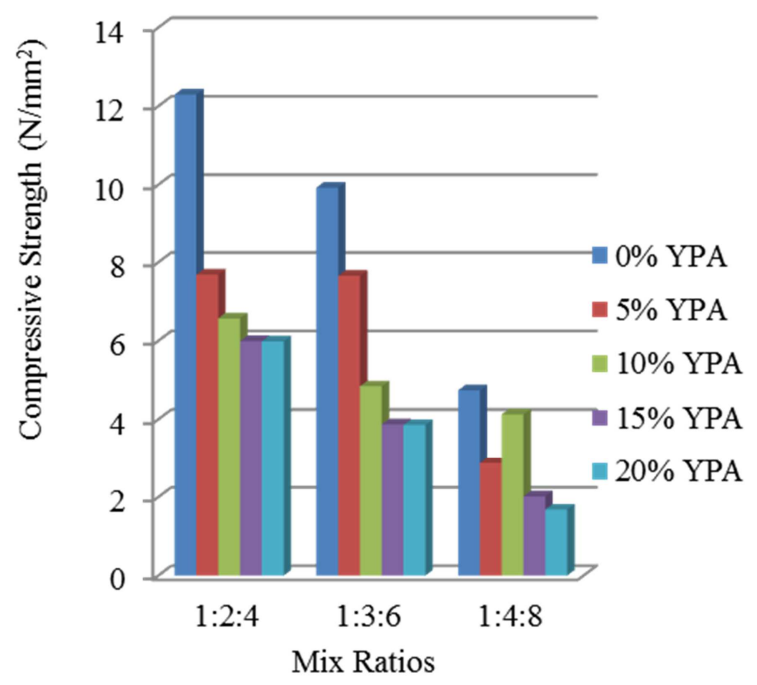

Figure 3. Compressive strength of concrete cubes for 21 days.

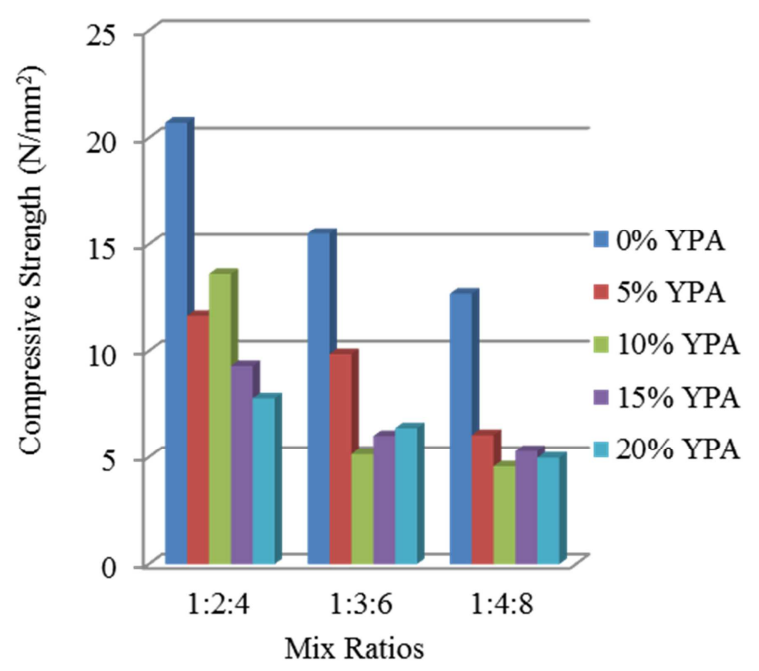

Figure 4. Compressive Strength of concrete cubes for 28days.

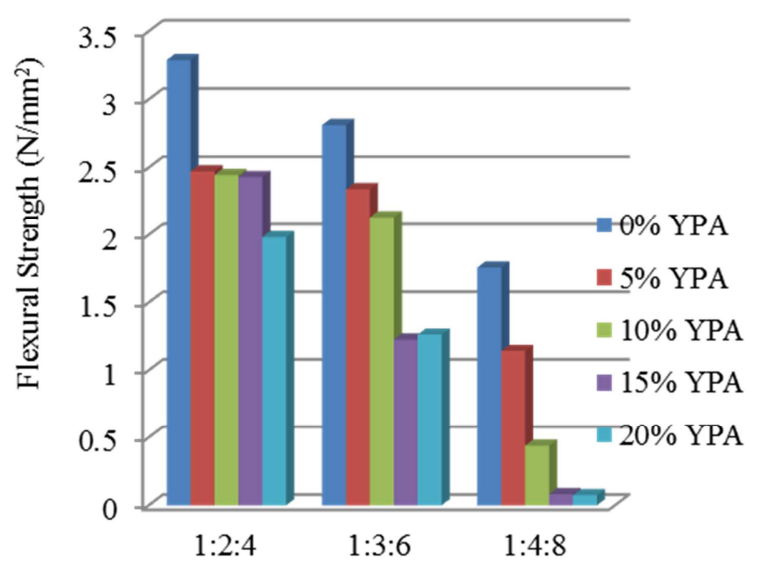

Mix Ratios

Figure 5. Flexural strength of concrete beams for 7 days. 


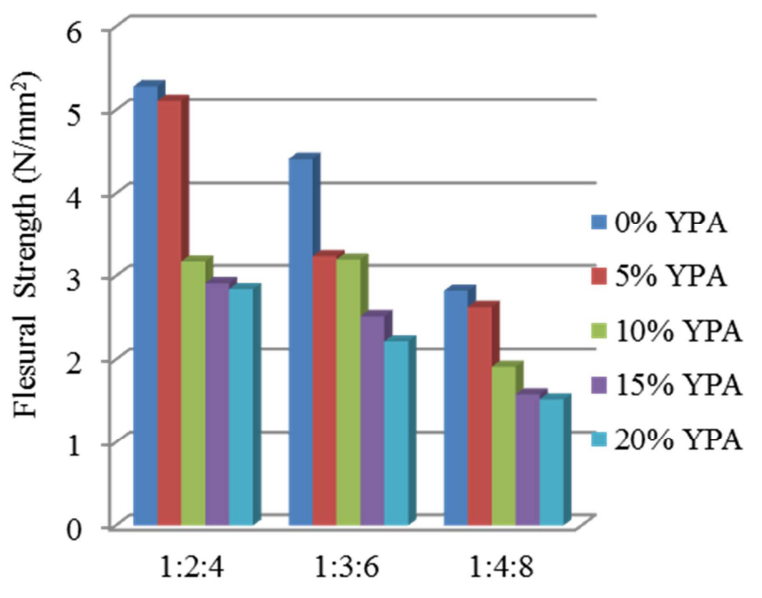

Mix Ratios

Figure 6. Flexural Strength of concrete beams for 28days.

\section{Conclusion}

The following conclusions were made from this research work:

The result revealed that the YPA has a slow reaction rate compared to cement.

Increment in YPA replacement of cement does not have any significant effect on the density of the test specimens of the blended concrete.

True slump was exhibited for concrete containing 5\%-20\% YPA for the three mixes of concrete.

Compressive and flexural strengths increase with age but reduce with increase in CPA content in the mix.

The Yam peel ash is suitable for replacement of cement in concrete when a mix ratio of 1:2:4 at 5\% YPA replacement is used for concrete beams.

\section{Acknowledgements}

The research work was made possible through the financial support from Tertiary Education Trust Fund (TETFUND) Institution Based Research Fund.

\section{References}

[1] Wa'el Alaghbari, Azizah Salim and Kamariah Dola (2009): Housing shortage for low-income in Yemen: Causes and suggestions. International Journal of Housing Markets and Analysis. 2 (4) 363-372.

[2] Igwe, P. U., Okeke C. A., Onwurah, K. O., Nwafor, D. C. and Umeh, C. N. (2017). A review of housing problems. International Journal of Environment, Agriculture and Biotechnology (IJEAB), 2 (6) 3092-3099.

[3] Ofuyatan, O., Ede, A., Olofinade, R., Oyebisi, S., Alayande, T. and Ogundipe J. (2018). Assessment of strength properties of cassava peel ash concrete. International Journal of Civil Engineering and Technology (IJCIET). 9 (1), 965-974.

[4] Olubajo, O. O. (2020). Effect of saw dust ash and eggshell powder on the properties of cement blends. The American
Journal ofConstruction and Building Materials. 4 (2), 88-99. doi: 10.11648/j.ajcbm.20200402.16.

[5] Olubajo, O. O., Nuuman, A. and Likita, N. S. (2020). The effect of sugarcane bagasse ash on the properties of Portland limestone cement. The American Journal ofConstruction and $\begin{array}{llll}\text { Building } & \text { Materials. } 4 \text { (2), 77-87. doi: }\end{array}$ 10.11648/j.ajcbm.20200402.15.

[6] Anosike, M. N. and Oyebade, A. A. (2012). Sandcrete blocks and quality management in Nigeria Building Industry. Journal of Engineering, Project, and Production Management, 2 (1), $37-46$.

[7] Dung, N. T., Hooper, T. J. N and Unluer, C. (2019). Accelerating the reaction kinectics and improving the performance of $\mathrm{Na}_{2} \mathrm{CO}_{3}$-activated GGBS mixes. Cement and Concrete Research, 126, 1-13.

[8] Manasseh, J. (2010). A review of partial replacement of cement with some agro wastes. Nigerian Journal of Technology, 29 (2), 12-20.

[9] De Sensale, G. R. (2006). Strength development of concrete with rice husk ash. Cement and Concrete Composites, 28 (2), 158-160.

[10] Chao-Lung, H., Le Anh-Tuan, B., and Chun-Tsun, C. (2011). Effect of rice husk ash on the strength and durability characteristics of concrete. Construction and building materials. 25 (9), 3768-3772.

[11] Ahmad, D. A. and Ado, M. (2016). Investigation in to the use of plantain peels ash as an admixture in concrete. International Journal of Engineering Science and Computing, 6 (5), 53775380 .

[12] Salau, M. A., Ikponmwosa, E. E. and Olonode K. A. (2012). Structural strength characteristics of cement-cassava peel ash blended concrete. Civil and Environmental Research, 2 (2), 68-77.

[13] Raheem, S. B., Arubike E. D., Awogboro, O. S. (2015). Effects of cassava peel ash (CPA) as alternative binder in concrete. International Journal of Constructive Research in Civil Engineering (IJCRCE). 1 (2), 27-32.

[14] Amartey, Y. D., Taku, J. K. and Sada, B. H. (2017). Optimization model for compressive strength of sandcrete blocks using cassava peel ash (CPA) blended cement mortar as binder. Kathmandu University Journal of Science, Engineering and Technology, 13 (2), 1-14.

[15] Adesanya, D. A. \& Raaheem, A. A. (2009). A study of the workability and compressive strength characteristics of corn cob ash blended cement concrete. Construction and Building Materials, 23 (1), 311-317.

[16] Ezeh, (1992), Economic of yam flour production; implications for research and development, and promotion of yam-based industries in Nigeria. Tropical Agriculture (Trindad), 69 (1), 51-57.

[17] Nweke, F. I., Uguwu, B. O. and Asadu C. L. A. and Ay, P. (1991), Production costs in the yam-based cropping systems of southeastern Nigeria. Resource of Crop Management Programme (RCMP) Research Monograph Number 6 RCMP, IITA Ibadan, Nigeria, pp 29.

[18] Fasina, O.(2014), Energy potential of yam and plantain peels. Agricultural Engineering International: CIGR Journal, 16 (2), 53-58. 
[19] Habeeb G. A, Fayyah M. M., (2009), Rice husk ash Concrete: the effect of RHA average particle size on mechanical properties and drying shrinkage. Australian Journal of Basic and Applied Science, 3 (3), 1616-1622.
[20] BS 1881-102: 1993. Method for determination of slump.

[21] BS1881- 107: 1993. Method for determination of density of compacted fresh concrete. 